\title{
ANALYSIS THE ABILITY OF STUDENT PROBLEM-SOLVING ON COUNTING OPERATIONS OF ALGEBRA FORM
}

\author{
Desy Yusnia \\ Universitas Ahmad Dahlan, Yogyakarta \\ desy1707050005@webmail.uad.ac.id
}

\begin{abstract}
ABSTRAK
Pemecahan masalah adalah bagian penting dari kurikulum pembelajaran matematika. Banyak siswa yang masih mengalami kesulitan dan kesalahan dalam menyelesaikan pemecahan masalah. Tujuan dari penelitian ini adalah untuk mengetahui kemampuan pemecahan masalah siswa dalam operasi hitung bentuk aljabar. penelitian ini merupakan penelitian deskriptif kualitatif. Subjek penelitian ini adalah siswa kelas VII-F SMP N 1 Wonosari. Teknik pengumpulan data yang digunakan adalah tes pemecahan masalah. Teknik analisis data yang digunakan berdasarkan analisis Miles dan Huberman, yaitu reduksi data, penyajian data, dan penarikan kesimpulan. Hasil dari penelitian ini menunjukkan bahwa: (1)95.56\% siswa dapat memahami masalah dengan baik, $4.44 \%$ siswa tidak dapat memahami masalah; (2) $18.33 \%$ siswa dapat membuat perencanaan penyelesaian masalah, $81.67 \%$ tidak dapat membuat perencanaan dengan baik; (3) $28.61 \%$ siswa dapat melakukan perencanaan dengan baik, $71.39 \%$ tidak dapat melakukan perencanaan; (4) 45\% melakukan pengecekan ulang jawaban dengan baik, 55\% tidak melakukan pengecekan jawaban.
\end{abstract}

Kata kunci: pemecahan masalah, kemampuan pemecahan masalah, operasi hitung bentuk aljabar.

\begin{abstract}
Problem-solving is the important part of mathematics curriculum. Most of student still have difficulties and mistakes in promblem solving. This research aims to know problem-solving ability of student on counting operations of algebra form. This research is a descriptive qualitative research. The subject is student grade VII-F SMP N 1 Wonosari. The data collecting technique is a problem-solving test. The data analysis according to Miles and Huberman, which are data reduction, data display, drawing and verifying conclusion. The results of this research showing that: (1) $95.56 \%$ of student can understand the problem, $4.44 \%$ of student cannot understand the problem; (2) $18.33 \%$ of student can devising a plan, $81.67 \%$ cannot devising a plan; (3) $28.61 \%$ of student can carrying out the plan, $71.39 \%$ cannot carrying out the plan; (4) $45 \%$ can looking back the answer, 55\% cannot looking back the answer.
\end{abstract}

Keywords: problem-solving, the ability of student problem-solving, counting operations of algebra form.

\section{INTRODUCTION}

Many student struggle to accomplish mathematics especially in problemsolving. However, they still need to learn mathematics because of its importance in daily life. Student must be able to solve problem because problem solving is important for the development of human competencies (Tambychik \& Meerah, 2010). Lester (2013) defined problem-solving as an activity that involves the student engagement in a variety of cognitive actions including accessing and 


\section{Desy Yusnia}

using previous knowledge and experience. Problem-solving in math is served as an analytical case question which guide the student to understand the content of the question first, then make a simple mapping in order to separate the information, found the question, by mathematical symbols until the question is answered. Most of the student make an error problem solving because they don't know what to be the basic concept. The final answer can't be mentioned as the parameter of student's mistakes, but student's process in answering the question too. This process makes the student know what to be their specific fault and motivates them for a better problem-solving. In the process of problem-solving, student must go through several phases before getting the final answer. Supianto et al., (2017) said that student ability to understand and resolve the problemsolving is still weak, that shows student' literacy skills are lacking. Based on Wardono \& Mariani (2014), mathematical literacy is the ability to formulate, implement, and interpret mathematics in a variety of situations including the ability to perform reasoning and use concepts, procedures, and facts to illustrate or explain a phenomenon.

According to Newman (in White, 2009) stated that there are five phases of problem-solving, namely reading, comprehension, transformation, process skills and encoding. Meanwhile, according to Polya (1973), the problem-solving process has four phases, namely understand the problem, devising a plan, carrying out the plan and looking back. Problem-solving is an activity that can generate Higher Order Thinking Skills (HOTS) among student. However, only a few student are capable of solving problems and many are experiencing difficulties (Abdullah, Abidin, \& Ali, 2015). So, the purpose of this research is to know problem-solving ability of student on counting operations problem of algebra form.

\section{RESEARCH METHOD}

This research belongs to descriptive qualitative research and is conducted in SMP Negeri 1 Wonosari, Gunung kidul for First Semester in 2016-2017 academic year. The subject of the research is the student in class VII-F SMP 
Negeri 1 Wonosari. While, the object of the research is the problem-solving ability of student in the material form of algebra arithmetic operations.

The technique of data collectionis a problem-solving test. Furthermore, the data instrument is divided into two, the basic instrument stands for the researcher and the supplementary instruments named as test. The test consists of 5 description questions about counting operations of algebra form. Questions done by student within 90 minutes. Then, the test results are analyzed using Polya's problem-solving procedures.

The data analysis technique of this research using Miles and Huberman (2014) theory that are data reduction, data display, drawing and verifying conclusion. Data reduction is refers to the process whereby the mass of qualitative data may obtain from test result, observation, interview transcripts, field notes and etc is reduces and organized. Data display organize, compress, and assemble information in the form of tables, chart, or graphical format. Then, from the analysis should allow to begin to develop conclusions that can then be verified through reference to existing field notes or further data collection.

\section{RESULTS AND DISCUSSIONS}

The result of student's problem-solving test according to Polya is follows as.

1. Understanding the problem

Fromthe 24 research subjects, $95.56 \%$ of student can understand the problem, find theinformation from the problem and can find the answers on demand. In addition, as many as $4.44 \%$ of student cannot find the information and questions from the the given question. The result of this study indicate the ability of student in understanding the problem According to Tambychik \& Meerah(2010), understanding the question is a crucial aspect in problemsolving. Because of the long sentences and many information involved, student got confused regarding to the objective in the problem. So, they could not bring the meaning to the problem or might misunderstand the meaning. This can be seen in the percentage of ability to understand the problem as in the following diagram. 


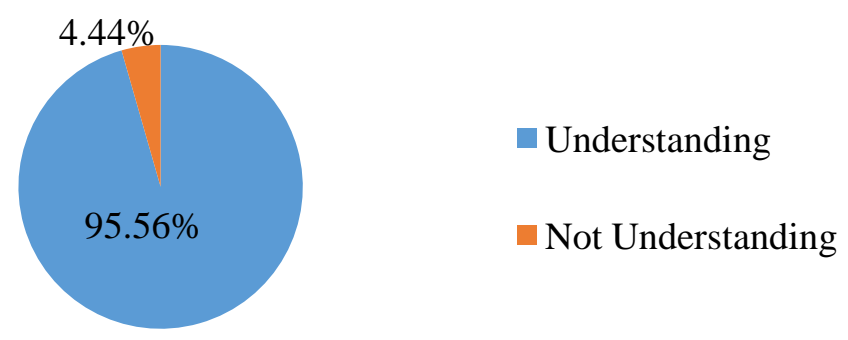

Figure 1: Percentage of student ability on understanding the problem

2. Devising a plan

From the 24 research subjects, $18.33 \%$ of the student were able to understand formaking a plan for completion or determining the formula used correctly in accordance with the demand question. In addition, as many as $81.67 \%$ of student cannot make a plan for completion or determine the right formula to use. The results of this study indicate that student' ability in making the settlement plan is not good. This result is supported by conducted research by Ninik, Hobri \& Suharto (2014) which state that the percentage of student in problem solving ablitity is low in the devising a plan is still quite high. According to Tambychik \& Meerah (2010), lack in these skills might lead to incompatible planning on how to execute the solving was difficult and incorrect. This can be seen in the percentage of ability to make a plan for completion as in the following diagram.

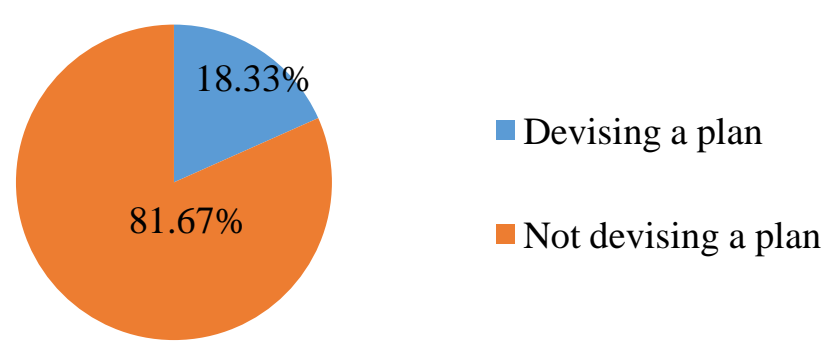

Figure 2: Percentage of student ability on devising a plan

3. Carrying out the plan

From the 24 research subjects, $28.61 \%$ of student can present the correct solution step. In addition, as many as $71.39 \%$ of student can not present the correct completion step. The results of this study indicate that the ability of 
student in implementing the settlement plan is not good. While performing the solving-procedure, they could not recall the facts necessary like the concepts, tables, and the calculation-working (Tambychik \& Meerah, 2010). This can be seen in the percentage of ability to execute the completion plan as in the following diagram.

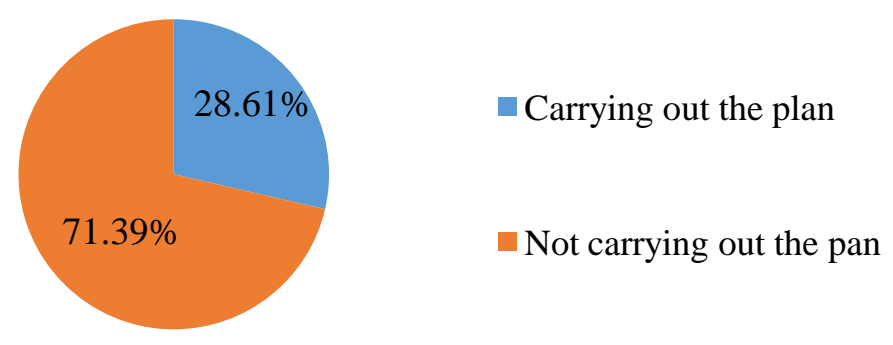

Figure 3: Percentage of student ability on carrying out the plan

\section{Verification}

From the 24 research subjects, as many as $45 \%$ of student can make correct conclusions and check the answers and process back. In addition, as many as $55 \%$ of student cannot make a correct conclusion and do not check repeated answers. The results of this study indicate that the ability of student in checking the answer back less good. According to Tambychik \& Meerah (2010), only $20 \%$ of the respondents carried out the clarification phase. Clarification phase have the same meaning with looking back phase. This can be seen in the percentage of checking ability as in the following diagram.

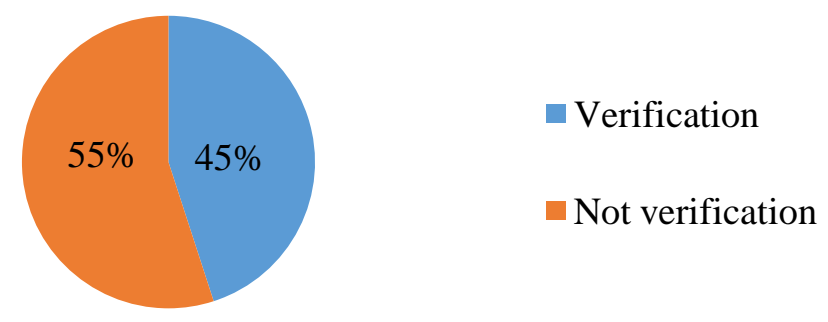

Figure 4: Percentage of student ability on verification

\section{CONCLUSION}

Based on the results of research and discussions, it can be concluded that $95.56 \%$ of student can understand the problem, $4.44 \%$ of student cannot 
understand the problem, $18.33 \%$ of student can devising a plan, $81.67 \%$ cannot devising a plan, $28.61 \%$ of student can carrying out the plan, $71.39 \%$ cannot carrying out the plan, $45 \%$ can looking back the answer, 55\% cannot verification the answer. Thus, the student problem-solving ability is still low. To improve problem-solving ability, student must often solve HOTS problems.

\section{REFFERENCE}

Abdullah, A. H., Abidin, N. L. Z., \& Ali, M. (2015). Analysis of student' errors in solving Higher Order Thinking Skills (HOTS) problems for the topic of a fraction. Asian Social Science Journal Volume 11, Number 21, 2015. Retrieved from https://doi.org/10.5539/ass.v11n21p133

Lester, F. K. (2013). The Mathematics Enthusiast Thoughts About Research On Mathematical Problem-Solving Instruction. The Mathematics Enthusiast Volume 10, Number 10, 2013. Retrieved from https://doi.org/ISSN 1551$\underline{3440}$

Miles, Matthew B. dan A. Micheal Huberman. (2014). "Analisis Data Kualitatif": Buku Sumber Tentang Metode-Metode Baru. Jakarta: Universitas Indoneisa Press.

Ninik, Hobri, \& Suharto. Analisis Kemampuan Pemecahan Masalah untuk Setiap Tahap Model Polya dari Siswa SMK Ibu Pakusari Jurusan Multimedia pada Pokok Bahasan Program Linier. Jurnal Kadikma Volum 5, Nomor 3. Desember 2014.

Polya, G. (1973). "How to Solve It": A New Aspect of Mathematical Method. Princeton: Princeton University Press.

Supianto, et al. Error Analysis Of Student Working About Word Problem Of Linear Program With NEA Procedure. Jurnal of Physics Volume 1, 2017.Retrieved from http://iopscience.iop.org/article/10.1088/17426596/855/1/012043/pdf

Tambychik \& Meerah. Student' Difficulties in Mathematics Problem-Solving: What do they Say?. Procedia Social and Behavioral Siences Volume 8. 2010. Retrieved from www.sciencedirect.com

Wardono \& Mariani, S. The Realistic Learning Model With Character Education And PISA AssessmentTo Improve Mathematics Literacy. International Journal of Education and Research Volume 2, Number 7, 2014. Retrieved from http://www.ijern.com/journal/July-2014/30.pdf

White, A. L. Diagnostic and Pedagogical Issues with Mathematical Word Problems. Brunei Int. J. of Sci. \& Math. Edu Volume 1, Number 1. 2009. Retrieved from https://shbieejournal.files.wordpress.com/2009/11/awhite 2009bijsmepdf.pdf 